\title{
WHAT MAKES BUSINESS GOING? \\ ACCOUNTING PROFIT VS \\ ECONOMIC PROFIT
}

\section{Dr. Bhavani Akkapeddi}

Pratishtha Bhardwaj, a student, was given a topic to speak on "Where students run to?"as part of an activity of 'English club' of her college. She spoke about the Bakery in the vicinity of their college, where the students spend their time to refresh and relax. Arzoo, her class mate was quite impressed for her style of presentation and English Language skills and shared the same with her friend Ankit. He did not pay any attention to the sophisticated English language or the very true experience of every other student. Her speech made him focus and observe the contradictions related to behavior of the Bakery. On the one hand Bakery was a busy place (see Figure 1), reflecting active business. On the other, he had noticed the frequent changes of ownership of Bakery - Fresh ' $n$ ' Tasty.He took change of ownership as a symptom of loss in business. As a passionate student of economics, he wanted to dig deeper into the business/economic aspect of this change of ownership of Fresh 'n' Tasty' and understand, what makes business going?

The following were the lines Pratishtha spoke about the Bakery, which gives a clear picture of activity, at the bakery.

"In the hectic PGDM life of a hostel student, the most convenient place of escape is the nearby Bakery - Fresh 'n' Tasty. Yes! It is situated right across the road in a way that hides the enormous gates, inside which our life rushes by among assignments, projects and presentations, and as we take that turn towards Fresh ' $n$ ' Tasty, we hear unhindered laughter of friends and join in.

As someone who frequents this small shop, known simply as the Bakery among the student community, I go there for all reasons. During exams it's the much needed coffee, or ice cream shakes,and drinks to sooth the exam fever. With its wide variety of junk food, from chips and cakes to Maggi and burgers as well as fruits and juices for the health conscious, it serves as a cheap alternative to our mess food. Being just a hop away, it saves time.

Be it any time of the day, you can see people flocking to the place. Not just us students but guys from the surrounding corporate like Tech Mahindra, TATA Consultancy Services, TATA Power, Infosys, General Electric, Dubas Engineering, and laborers from nearby construction sites. Everyone, small or big, can be seen at the place for the much needed break. As it caters to people from all surrounding areas, the Bakery is always full. Always.

It's not just the place you rush off to for a bite at the last minute, it is our rendezvous with friends living in the other hostel, it's the place where students blow out smoke circles, it's

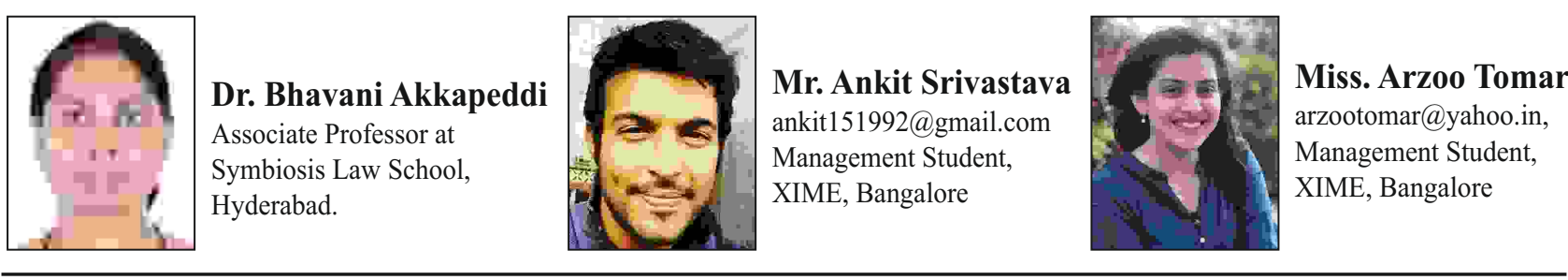


where the whole class sings and celebrates your birthday, It's where you can hear gossip and exchange stories, it's also the place where you are if you have nowhere else to be.

We go to nicer, starrier restaurants or clubs for planned parties, but the little memories we make over chai-coffee and noodles cannot be replaced. It is 'The Adda' . It is the hangout that helps us cope up with the fast pace of MBA life by providing us a place where we can pant at will.

Without exaggerations, Bakery is the place that will pop up into our heads as we reminisce our college life a few years down the line".

\section{The First Owner of Fresh ' $n$ ' Tasty'}

So the story goes like this; the first owner, Nanjundappa, who was in his forties, working with a small company as a security guard and earning Rs.10, 000 a month, was not at all happy with his job, after his father-in-law received a huge sum of Rs 2 crores. Nanjundappa's father-in-law inherited around half-an-acre of land in a village by name Avalahalli near Bangalore. The village became an inherent part of the Bangalore Urban Agglomeration and became a hot spot of real estate business. He sold his land as the price he got from the property was much higher than the yield he gets from it. Nanjundappa decided to start a Bakery, as it involves only buying and selling, and as he did not have any other skills. Nanjundappa succeeded in getting Rs.12 Lakhs from his father-in-law to start the business Bakery. He paid Rs. 10 Lakhs for acquiring the newly built premises of a shopping complex, in the midst of many software companies; and used Rs. 2 Lakhs for running the business. He started it with some of the basic snacks and juices. The activities of Nanjundappa's business included purchases and sales of biscuits, chips, chocolates, juices and shakes and cakes. He also employed a person to prepare juices and milk shakes by agreeing to pay Rs. 9000 per month and another woman to clean the surroundings, four times a day and agreed to pay Rs. 8000 per month. After a month he was surprised to see that electricity and water bill came to Rs. 10,000. He had never received such a bill for his residence. Then he came to know that, for commercial area, this was a normal bill for lighting, and the gadgets including refrigerator. He felt that the person he employed was not doing his work properly and hence, the business was not going good. There was also lot of absenteeism by the workers; and Nanjundappa believed that some amount of money that the worker collected from customers in his absence was not being returned. His total cost of goods was Rs. 2, 12, 014 and total revenue from selling goods was Rs. 2, 38, 565 (see Annexure - 1). When other regular expenses were added to the purchases of goods, expenditure was more, and revenue was less. He ran it for 3 months and did not feel that the business to be remunerative, and decided to sell it off, as people were ready to buy it for Rs. 15 Lakhs.

\section{The Second Owner of Fresh 'n' Tasty'}

It was the time when all students came back after their winter internship. It was an altogether new Bakery. Walls were painted with fruity colors and new menu was posted in bold on the walls. Many new items were added along with everyone's favorite "Noodles".

Kemmick \& Friends had taken over Fresh ' $n$ ' Tasty' from Nanjundappa. Kemmick's brother and Nanjundappa had a common friend, and through him they closed the deal. Kemmick, a fresh graduate from Kerala, came in search of a job to Bangalore, as he heard that Bangalore has lot many job opportunities for the educated; and as his brother got settled in 
Bangalore. Even his friends, Ben, Roger and Sandeep landed in Bangalore. Though they attended different interviews at different companies, none of them were able to crack any. As they felt guilty of telling people that they were unable to get into jobs and as they had some financial support from family, they decided to get into business and be on their own. They grabbed the opportunity of buying the Bakery, confident that they can delight customers of their age group. They came with a lot more eatables and a variety of juices and shakes to the menu. They did not hire anyone for preparing shakes and juices, but they continued the services of the woman for cleaning. On the one hand, they ran the Bakery with a lot of interest and on the other, attended interviews whenever they got a call. All of them were happy that the business was growing and customers were very happy with their services. They also started taking orders for celebrations of birthday parties, parties on the eve of promotions and salary hikes and farewell parties. After running it for three months, Sandeep got an opportunity at Wipro Technologies Ltd. with a CTC of 3.6 Lakhs per annum. Others continued with the business. However, in the next two months everyone got offers of similar kind with the date of joining fast approaching. When Kemmick \& Friends' were in a dilemma to continue with the growing business or join corporate, all their family, friends and relatives advised them to join corporate. The activities of Kemmick \& Friends' business included many more items compared to Nanjundappa's business and hence the cost of goods and revenue were also more. The total cost of goods was Rs. 4, 23, 037 and total revenue from selling goods was Rs. 5,55,357 (see Annexure - 2). When other regular expenses were added to the purchases of goods for Kemmick \& Friends' revenue was more than expenditure. Still they decided to sell it and take their shares as per their investments.

\section{The Third Owner of Fresh 'n' Tasty'}

Manjunath, a 40 year old man took over Fresh ' $\mathrm{n}$ ' Tasty from Kemmick \& Friends. Manjunath, though started his life as a daily labourer, continued to earn and save more and more year after year and had a house of his own and 2 acres of land in his remote native village. Manjunath, his wife, and his son, who was not interested to continue his studies after failing 10th class started working at their own Bakery. Even his daughter, who was a college going girl was helping them whenever she had a holiday. Manjunath's wife was doing all the cleaning and the services of the woman cleaning the premises were discontinued. The activities of Manjunath's Business had more or less the same activities as that of Kemmick\& Friends. He was able to make more revenue from fruit juices by reducing wastage. The total cost of goods was Rs. 4, 16, 884 and total revenue from selling goods was Rs. 7, 82, 340 (see Annexure - 3). When other regular expenses were added to the purchases of goods, revenue was more than expenditure. He continued the business.

\section{Figure 1: Photo Picturing the Business at Fresh 'n' Tasty}

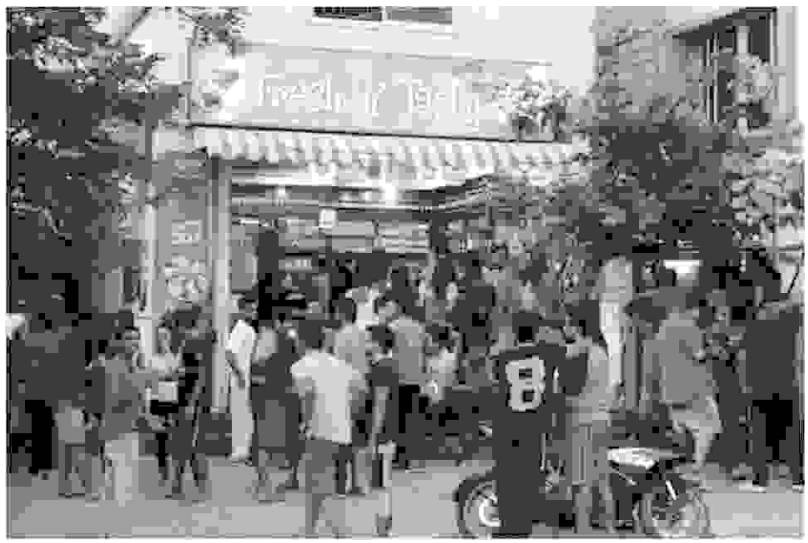


Annexure 1: Purchases and Sales of Nanjundappa's Business (in Rs. Per month)

\begin{tabular}{|c|c|c|c|c|c|c|}
\hline Products Sold & $\begin{array}{l}\text { Quantity } \\
\text { Procured }\end{array}$ & $\begin{array}{l}\text { Cost } \\
\text { per } \\
\text { Item }\end{array}$ & Total Cost & $\begin{array}{l}\text { Quantity } \\
\text { Sold }\end{array}$ & Price & $\begin{array}{l}\text { Total } \\
\text { Revenue }\end{array}$ \\
\hline \multirow[t]{3}{*}{ Biscuits } & 1270 & 4.5 & 5715 & 1270 & 5 & 6350 \\
\hline & 895 & 8.5 & 7607.5 & 840 & 10 & 8400 \\
\hline & 425 & 21 & 8925 & 350 & 25 & 8750 \\
\hline \multirow{3}{*}{ Chips } & 515 & 25.5 & 13132.5 & 417 & 30 & 12510 \\
\hline & 350 & 8.5 & 2975 & 333 & 10 & 3330 \\
\hline & 733 & 17.6 & 12900.8 & 733 & 20 & 14660 \\
\hline \multirow{5}{*}{ Chocolates } & 525 & 25.5 & 13387.5 & 400 & 30 & 12000 \\
\hline & 235 & 8.5 & 1997.5 & 200 & 10 & 2000 \\
\hline & 125 & 19 & 2375 & 73 & 25 & 1825 \\
\hline & 35 & 39.6 & 1386 & 7 & 45 & 315 \\
\hline & 40 & 88 & 3520 & 4 & 100 & 400 \\
\hline \multirow[t]{2}{*}{ Juices and Shakes } & 520 & 80 & 41600 & 1708 & 20 & 34160 \\
\hline & 170 & 70 & 11900 & 833 & 35 & 29155 \\
\hline & 105 & 180 & 18900 & 1067 & 50 & 53350 \\
\hline \multirow{5}{*}{ Cakes } & 300 & 15 & 4500 & 300 & 20 & 6000 \\
\hline & 425 & 22.5 & 9562.5 & 417 & 30 & 12510 \\
\hline & 165 & 122 & 20130 & 107 & 150 & 16050 \\
\hline & 150 & 210 & 31500 & 84 & 200 & 16800 \\
\hline & & & 212014.3 & & & 238565 \\
\hline
\end{tabular}

Source: Primary Data collected and compiled, based on interviews with the current owner, customers of Bakery - Fresh 'n' Tasty, and observations of authors. Data was collected during June and July 2016.

\section{Notes:}

1. Biscuits included, Tiger, Cookies, Maska Chaska, Dream Cream, Moms Magic ; Chips included,Lays, Bingo ; Chocolates included, Dairy Milk, Munch, Gems, Milkybar ; Juices and Shakes included, Apple, Sweet Lemon, Pomegranate; Cakes included, Brittania .

2. For Juices, (Fruits procured in kg's) The price of sweet lemon - Rs. 80/-; Pomegranate - Rs. 70/-; Apple - Rs. 180/-

3 . The average number of glasses of juice per $\mathrm{kg}$ of fruit (including wastage of fruit due to spoilage) : sweet lemon (Mausambi) 3 glasses; Pomegranate - 5 glasses; Apple - 10 glasses 


\begin{tabular}{|c|c|c|c|c|c|c|}
\hline \multicolumn{7}{|c|}{ Annexure 2: Purchases and Sales of Kemmick's Business } \\
\hline Products Sold & $\begin{array}{l}\text { Quantity } \\
\text { Procured }\end{array}$ & $\begin{array}{l}\text { Cost } \\
\text { per } \\
\text { Item }\end{array}$ & Total Cost & $\begin{array}{l}\text { Quantity } \\
\text { Sold }\end{array}$ & Price & $\begin{array}{l}\text { Total } \\
\text { Revenue }\end{array}$ \\
\hline \multirow[t]{4}{*}{ Biscuits } & 673 & 4.5 & 3028.5 & 673 & 5 & 3365 \\
\hline & 200 & 17.6 & 3520 & 173 & 20 & 3460 \\
\hline & 920 & 21 & 19320 & 840 & 25 & 21000 \\
\hline & 1140 & 25.5 & 29070 & 1066 & 40 & 42640 \\
\hline \multirow[t]{3}{*}{ Chips } & 900 & 8.5 & 7650 & 900 & 10 & 9000 \\
\hline & 1250 & 17.6 & 22000 & 1187 & 20 & 23740 \\
\hline & 700 & 25.5 & 17850 & 610 & 30 & 18300 \\
\hline \multirow[t]{4}{*}{ Chocolates } & 750 & 8.5 & 6375 & 710 & 10 & 7100 \\
\hline & 220 & 39.6 & 8712 & 140 & 45 & 6300 \\
\hline & 220 & 72 & 15840 & 140 & 85 & 11900 \\
\hline & 260 & 88 & 22880 & 170 & 100 & 17000 \\
\hline \multirow[t]{3}{*}{ Juice and Shakes } & 288 & 80 & 23040 & 1440 & 25 & 36000 \\
\hline & 125 & 70 & 8750 & 875 & 40 & 35000 \\
\hline & 128 & 180 & 23040 & 1280 & 50 & 64000 \\
\hline \multirow[t]{3}{*}{ Cakes } & 375 & 21.5 & 8062.5 & 350 & 25 & 8750 \\
\hline & 160 & 170 & 27200 & 90 & 200 & 18000 \\
\hline & 120 & 252 & 30240 & 75 & 300 & 22500 \\
\hline Sandwich & 540 & 45 & 24300 & 1372 & 35 & 48020 \\
\hline French Fries & 375 & 30 & 11250 & 750 & 40 & 30000 \\
\hline \multirow[t]{3}{*}{ Cigarettes } & 1000 & 4.5 & 4500 & 1000 & 5 & 5000 \\
\hline & 2200 & 8.5 & 18700 & 2170 & 10 & 21700 \\
\hline & 1895 & 12.5 & 23687.5 & 1850 & 15 & 27750 \\
\hline \multirow[t]{4}{*}{ Soft Drinks } & 840 & 10.2 & 8568 & 806 & 12 & 9672 \\
\hline & 290 & 17.6 & 5104 & 282 & 20 & 5640 \\
\hline & 1900 & 26.5 & 50350 & 1860 & 32 & 59520 \\
\hline & & & 423037.5 & & & 555357 \\
\hline
\end{tabular}

Source: Primary Data collected and compiled, based on interviews with the current owner, customers of Bakery - Fresh 'n' Tasty, and observations of authors. Data was collected during June and July 2016.

\section{Notes:}

1. Biscuits included, Moms Magic, Tiger, Bourbon, Dream Cream, Oreo; Chips included, Lays, Bingo, Uncle Chips; Chocolates included, Milkybar, Dairy Milk, Gems, Bar One, Munch, Celebrations; Juice and Shakes included, Apple, Pomegranate, Sweet Lemon; Cakes included, Brittania, Winkies; Cigarettes included, Gold flake, Silk Cut , Capstain; Soft Drinks included, Mountain Dew, Thums Up, Fanta, Sprite, Coca Cola.

2. For Juices, it is Kgs. of Fruits procured. The price of sweet lemon - Rs. 80/-; Pomegranate - Rs. 70/;Apple - Rs. 180/-

3. The average number of glasses of juice per $\mathrm{kg}$ of fruit(including wastage of fruit due to spoilt): Sweet Lemon - 3to 4 glasses; Apple - 10 glasses; Pomegranate - 8 glasses.

4. The price of $1 \mathrm{~kg}$ of potato was Rs 30 and was used in making Sandwiches and French Fries. 


\begin{tabular}{|c|c|c|c|c|c|c|}
\hline \multicolumn{7}{|c|}{ Annexure 3: Purchases and Sales of Manjunath's Business } \\
\hline Products Sold & $\begin{array}{l}\text { Quantity } \\
\text { Procured }\end{array}$ & $\begin{array}{l}\text { Cost per } \\
\text { Item }\end{array}$ & Total Cost & $\begin{array}{l}\text { Quantity } \\
\text { Sold }\end{array}$ & Price & $\begin{array}{l}\text { Total } \\
\text { Revenue }\end{array}$ \\
\hline \multirow[t]{4}{*}{ Biscuits } & 1380 & 4.5 & 6210 & 1366 & 5 & 6830 \\
\hline & 1645 & 8.5 & 13982.5 & 1640 & 10 & 16400 \\
\hline & 1160 & 21.5 & 24940 & 1150 & 25 & 28750 \\
\hline & 1250 & 34.6 & 43250 & 1200 & 40 & 48000 \\
\hline \multirow{3}{*}{ Chips } & 400 & 8.5 & 3400 & 383 & 10 & 3830 \\
\hline & 1030 & 17.6 & 18128 & 1030 & 20 & 20600 \\
\hline & 525 & 25.5 & 13387.5 & 516 & 30 & 15480 \\
\hline \multirow[t]{4}{*}{ Chocolates } & 226 & 17.6 & 3977.6 & 226 & 20 & 4520 \\
\hline & 410 & 35 & 14350 & 405 & 40 & 16200 \\
\hline & 130 & 88 & 11440 & 106 & 100 & 10600 \\
\hline & 150 & 132 & 19800 & 140 & 150 & 21000 \\
\hline \multirow[t]{3}{*}{ Juice and Shakes } & 98 & 80 & 7840 & 490 & 25 & 12250 \\
\hline & 510 & 70 & 35700 & 4080 & 40 & 163200 \\
\hline & 230 & 180 & 41400 & 2750 & 55 & 151250 \\
\hline \multirow[t]{3}{*}{ Cakes } & 200 & 15.5 & 3100 & 190 & 20 & 3800 \\
\hline & 145 & 76 & 11020 & 140 & 100 & 14000 \\
\hline & 90 & 230 & 20700 & 85 & 300 & 25500 \\
\hline Sandwich & 60 & 45 & 2700 & 119 & 45 & 5355 \\
\hline French Fries & 25 & 30 & 750 & 50 & 55 & 2750 \\
\hline \multirow[t]{2}{*}{ Ice Cream } & 1080 & 17.6 & 19008 & 1080 & 20 & 21600 \\
\hline & 280 & 42.5 & 11900 & 265 & 50 & 13250 \\
\hline \multirow[t]{3}{*}{ Soft Drinks } & 540 & 17.6 & 9504 & 540 & 20 & 10800 \\
\hline & 640 & 25.5 & 16320 & 620 & 30 & 18600 \\
\hline & 845 & 39.6 & 33462 & 830 & 45 & 37350 \\
\hline \multirow[t]{2}{*}{ Momos } & 120 & 30 & 3600 & 355 & 50 & 17750 \\
\hline & 50 & 150 & 7500 & 316 & 60 & 18960 \\
\hline Bread Omelet & 1020 & 6 & 6120 & 540 & 50 & 27000 \\
\hline \multirow[t]{3}{*}{ Snacks } & 55 & 5 & 275 & 300 & 10 & 3000 \\
\hline & 80 & 15 & 1200 & 350 & 25 & 8750 \\
\hline & 65 & 20 & 1300 & 285 & 35 & 9975 \\
\hline \multirow[t]{4}{*}{ Noodles } & 52 & 35 & 1820 & 106 & 40 & 4240 \\
\hline & 85 & 50 & 4250 & 205 & 50 & 10250 \\
\hline & 70 & 65 & 4550 & 150 & 70 & 10500 \\
\hline & & & 416884.6 & & & 782340 \\
\hline
\end{tabular}

Source: Primary Data collected and compiled, based on interviews with the current owner, customers of Bakery - Fresh 'n' Tasty, and observations of authors. Data was collected during June and July 2016.

\section{Notes:}

1. Biscuits included, 50-50, Maska Chaska, Moms Magic, Parle Americana, Dark Fantasy, Bourbon, Oreo, Chunkies, Dream Cream, Jim Jam, Digestive , Little Hearts ; Chips included, Lays, Tedhe Medhe, Bingo , Uncle Chips, Cheetos; Chocolates included, Dairy milk, Silk, Schmitten, 5 star, Kit kat, Nutties, Milkybar, Celebrations, Bournville; Juices included, Apple, Pomegranate, Sweet Lemon; Cakes included, Brittania, Winkies; Soft Drinks included, Mountain Dew, Pepsi, Thums Up, Coca Cola, Fanta, Mirinda, RC Cola, Paper Boat.

2. For Juices, it is Kgs. of Fruits procured. The price of sweet lemon - Rs. 80/-; Pomegranate - Rs. 70/-; Apple Rs. 180/-

3. The average number of glasses of juice per fruit (including wastage of fruit due to spoilt): Sweet Lemon ( Mausambi) - 5-6 glasses; Apple - 12 glasses; Pomegranate- 8 glasses.

4. The price of $1 \mathrm{~kg}$ of potato was Rs 30 and was used in making Sandwiches and French Fries. 